Louisiana State University

LSU Digital Commons

$2-1-2007$

\title{
Degradation of STAT5 proteins in 3T3-L1 adipocytes is induced by TNF- $\alpha$ and cycloheximide in a manner independent of STAT5A activation
}

\author{
Z. Elizabeth Floyd \\ Louisiana State University \\ Brant M. Segura \\ Louisiana State University \\ Fang $\mathrm{He}$ \\ Louisiana State University \\ Jacqueline M. Stephens \\ Louisiana State University
}

Follow this and additional works at: https://digitalcommons.Isu.edu/biosci_pubs

\section{Recommended Citation}

Floyd, Z., Segura, B., He, F., \& Stephens, J. (2007). Degradation of STAT5 proteins in 3T3-L1 adipocytes is induced by TNF- $\alpha$ and cycloheximide in a manner independent of STAT5A activation. American Journal of Physiology - Endocrinology and Metabolism, 292 (2) https://doi.org/10.1152/ajpendo.00334.2006

This Article is brought to you for free and open access by the Department of Biological Sciences at LSU Digital Commons. It has been accepted for inclusion in Faculty Publications by an authorized administrator of LSU Digital Commons. For more information, please contact ir@lsu.edu. 


\title{
Degradation of STAT5 proteins in 3T3-L1 adipocytes is induced by TNF- $\alpha$ and cycloheximide in a manner independent of STAT5A activation
}

\author{
Z. Elizabeth Floyd, Brant M. Segura, Fang He, and Jacqueline M. Stephens \\ Department of Biological Sciences, Louisiana State University, Baton Rouge, Louisiana
}

Submitted 10 July 2006; accepted in final form 19 September 2006

Floyd ZE, Segura BM, He F, Stephens JM. Degradation of STAT5 proteins in 3T3-L1 adipocytes is induced by TNF- $\alpha$ and cycloheximide in a manner independent of STAT5A activation. Am J Physiol Endocrinol Metab 292: E461-E468, 2007. First published September 19, 2006; doi:10.1152/ajpendo.00334.2006.-Tumor necrosis factor- $\alpha(\mathrm{TNF}-\alpha)$ is a multifunctional cytokine that has been implicated as a causative factor in obesity-linked insulin resistance. It is commonly accepted that macrophage-derived TNF- $\alpha$ acts in a paracrine manner on adjacent adipocytes to inhibit the expression of various adipocyte genes and to attenuate insulin signaling. Several studies have revealed that signal transducer and activator of transcription (STAT)5 proteins are modulated during adipogenesis and can modulate the transcription of some adipocyte genes. In this study, we demonstrate that $\mathrm{TNF}-\alpha$ treatment, in the presence of cycloheximide, also results in the rapid turnover of STAT5A and STAT5B in a process that is independent of STAT5 activation by tyrosine phosphorylation. In addition, STAT5B is more labile than STAT5A under these conditions, suggesting that the $\mathrm{COOH}$ terminus of STAT5 may be involved in the turnover of each protein. Initial characterization of the TNF- $\alpha$ and cycloheximide-mediated degradation of STAT5 indicates that inhibition of the proteasome stabilizes both forms of STAT5 in the presence of TNF- $\alpha$. In addition, the use of an NF- $\kappa$ B inhibitor results in the stabilization of STAT5A in the presence of TNF- $\alpha$ and cycloheximide, indicating that the degradation of STAT5 proteins under these conditions may involve the NF-кB pathway. STAT5 proteins are abundantly expressed in mature adipocytes and are normally extremely stable proteins under a wide range of conditions. However, our results demonstrate that the potentiation of TNF- $\alpha$ mediated signaling in the presence of cyclohexmide is associated with a significant increase in the degradation of STAT5 proteins in 3T3-L1 adipocytes.

signal transducer and activator of transcription-5; tumor necrosis factor- $\alpha$; proteasome; nuclear factor- $\kappa \mathrm{B}$

THE SIGNAL TRANSDUCER AND ACTIVATOR of transcription (STAT) family of proteins are central regulators of cytokine-mediated signaling events in cell growth and differentiation. STAT proteins are latent transcription factors that are activated through tyrosine phosphorylation via interactions with cytokine receptor-associated Janus tyrosine kinases (JAK) or growth factor receptor tyrosine kinases (22). STAT5A and STAT5B are activated by growth hormone-mediated signaling and are highly induced during adipogenesis. A number of studies indicate that STAT5 proteins are important in adipocyte function $(10,30,38)$. Evidence that STAT5 proteins play a role in adipocytes includes studies demonstrating that ectopic expression of STAT5A confers adipogenesis in nonprecursor cell lines (10), expression of a dominant-negative form of STAT5

Address for reprint requests and other correspondence: J. M. Stephens, George C. Kent Professor, Dept. of Biological Sciences, Louisiana State University, 202 Life Sciences Bldg., Baton Rouge, LA 70803 (e-mail: jsteph1@1su.edu). inhibits lipid accumulation during adipogenesis (33), and constitutively active STAT5 can replace the requirement for growth hormone in adipogenesis (40).

TNF- $\alpha$ is a multifunctional cytokine that is highly expressed in adipose tissue and contributes to the development of insulin resistance associated with obesity (reviewed in Refs. 18, 36). Although the mechanism of TNF- $\alpha$-mediated insulin resistance is not entirely understood, $\mathrm{TNF}-\alpha$ treatment results in the downregulation of a range of genes required for insulin signaling, including GLUT4, insulin receptor (IR), insulin receptor substrate-1 (IRS-1) $(35,39)$, and the protein kinase Akt (7). A recent study suggests that $N F-\kappa B$ activation is required for a variety of effects that TNF- $\alpha$ has on adipocytes (35).

In the present study, we present evidence that, in the presence of cycloheximide, TNF- $\alpha$ mediates a substantial downregulation of STAT5 proteins in adipocytes via a pathway that appears to involve NF- $\mathrm{BB}$ and leads to the destabilization of STAT5A and STAT5B proteins. The TNF- $\alpha$-mediated increased turnover of STAT5 is dependent on the presence of cycloheximide under acute or chronic conditions, indicating that potentiation of $\mathrm{TNF}-\alpha$ signaling in adipocytes is associated with decreased expression of STAT5 proteins. Other studies have shown that TNF- $\alpha$ mediates decreases in Akt protein levels in adipocytes, an effect that is also enhanced in the presence of cycloheximide (25). Taken together, these studies indicate that TNF- $\alpha$, in addition to regulating gene expression at the transcriptional level, also regulates the degradation of proteins in adipocytes. Destabilization of adipocyte proteins via TNF- $\alpha$-dependent mechanisms in adipocytes may represent an additional pathway involved in the development of insulin resistance associated with obesity.

\section{MATERIALS AND METHODS}

Materials. Dulbecco's modified Eagle's medium (DMEM) was purchased from Life Technologies. Bovine and fetal bovine serums (FBS) were obtained from Sigma and Life Technologies, respectively. Murine TNF- $\alpha$ was purchased from Biosource International. Cycloheximide, wortmannin, $\mathrm{N}$-p-tosyl-L-phenylalanine chloromethyl ketone (TPCK), growth hormone, insulin, and U-0126 were purchased from Sigma. MG-132 was obtained from Boston Biochem. The non-phospho-STAT antibodies were a mouse monoclonal antibody purchased from Transduction Laboratories (STAT5B) and a rabbit polyclonal antibody from Santa Cruz Biotechnology (STAT5A). A highly phospho-specific polyclonal antibody for STAT5 ( $\left.{ }^{694}\right)$ was purchased from Upstate Biotechnologies.

Cell culture. Murine 3T3-L1 preadipocytes were plated and grown to 2 days postconfluence in DMEM with $10 \%$ bovine serum. Medium was changed every $48 \mathrm{~h}$. Cells were induced to differentiate by having

\footnotetext{
The costs of publication of this article were defrayed in part by the payment of page charges. The article must therefore be hereby marked "advertisement" in accordance with 18 U.S.C. Section 1734 solely to indicate this fact.
} 
the medium changed to DMEM containing a standard induction cocktail of $10 \%$ FBS, $0.5 \mathrm{mM}$ 3-isobutyl-1-methylxanthine, $1 \mu \mathrm{M}$ dexamethasone, and $1.7 \mu \mathrm{M}$ insulin (MDI). After $48 \mathrm{~h}$, this medium was replaced with DMEM supplemented with $10 \%$ FBS, and cells were maintained in this medium.

Preparation of whole cell extracts. Cell monolayers were rinsed with phosphate-buffered saline and harvested in a nondenaturing buffer containing $150 \mathrm{mM} \mathrm{NaCl}, 10 \mathrm{mM}$ Tris, $\mathrm{pH}$ 7.4, $1 \mathrm{mM}$ EGTA, $1 \mathrm{mM}$ EDTA, $1 \%$ Triton X-100, 0.5\% Nonidet P-40, $1 \mu \mathrm{M}$ PMSF, 1 $\mu \mathrm{M}$ pepstatin, 50 trypsin inhibitory milliunits of aprotinin, $10 \mu \mathrm{M}$ leupeptin, and $2 \mathrm{mM}$ sodium vanadate. Samples were extracted for 30 min on ice and centrifuged at $15,000 \mathrm{rpm}$ at $4^{\circ} \mathrm{C}$ for $15 \mathrm{~min}$. Supernatants containing whole cell extracts were analyzed for protein concentrations using a bicinchoninic acid kit (Pierce) according to the manufacturer's instructions.

Nuclear and cytoplasmic fractionation. Cell monolayers were rinsed with phosphate-buffered saline and harvested in a nuclear homogenization buffer containing $20 \mathrm{mM}$ Tris ( $\mathrm{pH} 7.4$ ), $10 \mathrm{mM} \mathrm{NaCl}$, and $3 \mathrm{mM} \mathrm{MgCl}_{2}$. Nonidet $\mathrm{P}-40$ was added to a final concentration of $0.15 \%$, and cells were homogenized with 16 strokes in a Dounce homogenizer. Homogenates were centrifuged to obtain nuclear and cytoplasmic extracts. Nuclear extracts were suspended in a nondenaturing buffer containing $10 \mathrm{mM}$ Tris ( $\mathrm{pH} 7.4$ ), $150 \mathrm{mM} \mathrm{NaCl}, 1$ mM EGTA, 1 mM EDTA, $1 \%$ Triton X-100, 0.5\% Nonidet P-40, 1 $\mu \mathrm{M}$ phenylmethylsulfonyl fluoride, $1 \mu \mathrm{M}$ pepstatin, 50 trypsin inhibitory milliunits of aprotinin, $10 \mu \mathrm{M}$ leupeptin, and $2 \mathrm{mM}$ sodium vanadate. Triton X-100 was added to cytoplasmic extracts to a final concentration of $1 \%$.

$T N F-\alpha$ and growth hormone treatment of 3T3-L1 adipocytes. TNF- $\alpha(5 \mathrm{nM})$ was added to developing or fully differentiated 3T3-L1 adipocytes for the indicated times. Growth hormone $(250 \mathrm{ng} / \mathrm{ml})$ was added as indicated. Cycloheximide $(5 \mu \mathrm{M})$ was present in experiments examining the effect of TNF- $\alpha$ or growth hormone on STAT5 half-life. The adipocytes were incubated with a panel of inhibitors (10 $\mu \mathrm{M}$ MG-132, $5 \mu \mathrm{M}$ U-0126, $200 \mathrm{nM}$ wortmannin, or $10 \mu \mathrm{M}$ TPCK) in experiments designed to characterize the mechanism of STAT5 turnover. STAT5 (5A and 5B) and STAT5-phosphotyrosine expression was analyzed by Western blot analysis.

Gel electrophoresis and immunoblotting. Proteins were separated in $7.5 \%$ polyacrylamide (National Diagnostics) gels containing SDS, as previously described (10), and transferred to nitrocellulose (BioRad) in $25 \mathrm{mM}$ Tris, $192 \mathrm{mM}$ glycine, and 20\% methanol. Following transfer, the membrane was blocked in $4 \%$ milk for $1 \mathrm{~h}$ at room temperature. Results were visualized with horseradish peroxidaseconjugated secondary antibodies (Sigma) and enhanced chemiluminescence (Pierce).

Half-life determinations. Un-Scan-It version 5.1 (Silk Scientific) was used to quantify Western blot data for STAT5A and STAT5B obtained under control and TNF- $\alpha$-treated conditions. Each experiment was performed three times independently, and the average and SD are reported for each condition.

\section{RESULTS}

TNF- $\alpha$ treatment destabilizes STAT5A in fully differentiated 3T3-L1 adipocytes. Several recent studies have shown that STAT5 proteins play an important role in adipogenesis $(10,30$, 33). We demonstrated that STAT5A, but not STAT5B, expression is sufficient to promote adipogenesis in non-precursor cells (10). Although STAT5B alone is not adipogenic, expression of STAT5B does enhance the adipogenic potential of STAT5A. In the course of examining the regulation of STAT5 in fully differentiated adipocytes, we noted that exposure to cycloheximide only resulted in a loss of STAT5A protein expression when TNF- $\alpha$ was present (Fig. 1A). The levels of extracellular signal-regulated kinase (ERK)1 were examined to
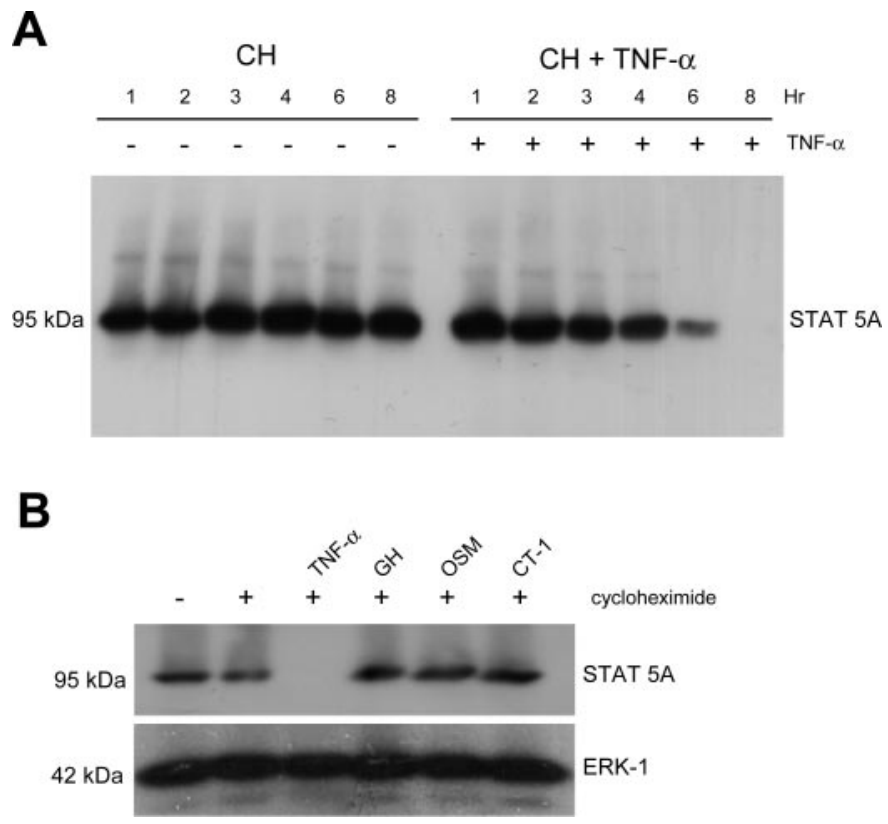

Fig. 1. TNF- $\alpha$ treatment in the presence of cycloheximide $(\mathrm{CH})$ destabilizes signal transducer and activator of transcription (STAT) $5 \mathrm{~A}$ in fully differentiated 3T3-L1 adipocytes. A: fully differentiated 3T3-L1 adipocytes were treated with $5 \mu \mathrm{M} \mathrm{CH}$ in the presence (TNF- $\alpha$ ) or absence (control) of $5 \mathrm{nM} \mathrm{TNF-} \alpha$ and harvested at the indicated time points. $B$ : fully differentiated 3T3-L1 preadipocytes were treated with TNF- $\alpha$ (TNF, $2 \mathrm{nM})$, growth hormone $(\mathrm{GH}$, $250 \mathrm{ng} / \mathrm{ml})$, oncostatin M (OSM, $0.5 \mathrm{ng} / \mathrm{ml})$, or cardiotropin-1 (CT-1, $0.2 \mathrm{nM})$ for $6 \mathrm{~h}$ in the presence of $5 \mu \mathrm{M} \mathrm{CH}$. Whole cell extracts were harvested after $6 \mathrm{~h}$. In each experiment, $100 \mu \mathrm{g}$ of each extract were separated by SDS-PAGE, transferred to nitrocellulose, and subjected to Western blot analysis using anti-STAT5A, anti-STAT3, anti-STAT5B, or anti-extracellular signal-regulated kinase (ERK)1 antibodies and visualized with horseradish peroxidase (HRP)-conjugated secondary antibodies and chemiluminescence. This is a representative experiment independently performed 3 times.

confirm even loading of protein extracts (data not shown). To determine whether the effect was specific for $\mathrm{TNF}-\alpha$, we examined the expression of STAT5 proteins following treatment with cyclohexmide and other cytokines that modulate adipocyte gene expression. As shown in Fig. $1 B$, the steadystate levels of STAT5A were undetectable in the presence of TNF- $\alpha$ and cycloheximide. However, the presence of cycloheximide with either growth hormone, oncostatin $\mathrm{M}$, or cardiotrophin-1 did not affect STAT5 protein levels under these conditions. The levels of ERK1 are shown to indicate even loading of protein extracts. The cells do not appear to be undergoing apoptosis, as has been reported for TNF- $\alpha$-mediated effects in the presence of cycloheximide $(32,49)$, since the levels of ERK1 protein were unchanged.

We also determined the location(s) of STAT5 turnover. The results in Fig. 2 indicate that the loss of STAT5A was not limited to the cytoplasm. When STAT5 levels in fully differentiated 3T3-L1 adipocytes are measured without serum deprivation, substantial amounts of STAT5A are found in the nucleus, possibly due to the presence of growth hormone in the serum (40). Our measurements of TNF- $\alpha$-mediated STAT5A turnover in cytoplasm and nuclear fractions show that both populations of STAT5A proteins are destabilized in the presence of TNF- $\alpha$ and cycloheximide. Even loading of protein extracts was confirmed (data not shown). 


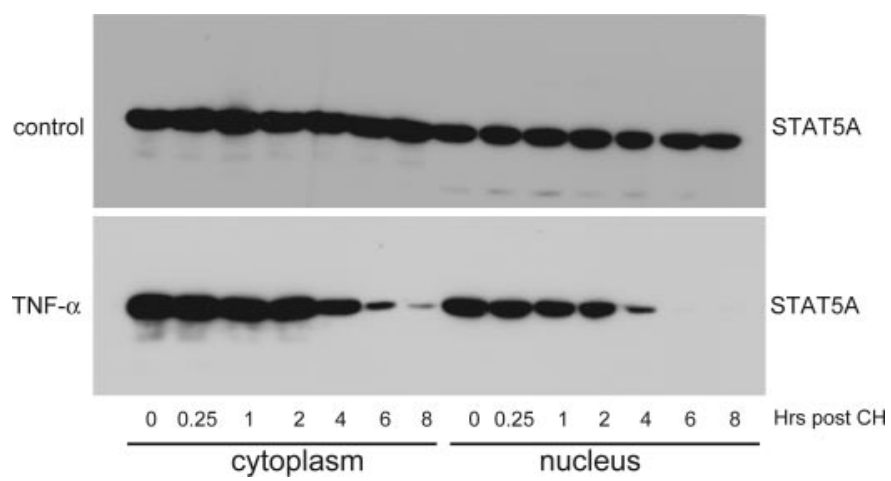

Fig. 2. Cytoplasmic and nuclear STAT5A proteins are destabilized by TNF- $\alpha$. Fully differentiated 3T3-L1 adipocytes were treated with $5 \mu \mathrm{M} \mathrm{CH}$ for the indicated time in the presence (TNF- $\alpha$ ) or absence (control) of $5 \mathrm{nM} \mathrm{TNF-} \alpha$. Extracts were fractionated into cytoplasmic and nuclear components, as described in MATERIALS AND METHODS, and $100 \mu \mathrm{g}$ of each extract were separated by SDS-PAGE. Following transfer to nitrocellulose, the samples were analyzed by Western blotting using an anti-STAT5A antibody. The experiment was carried out in triplicate and performed independently twice.

TNF- $\alpha$ does not activate STAT5A or affect growth hormonemediated STAT5A activation. Previous studies indicating that TNF- $\alpha$ induces phosphorylation of STAT5A in the rat hypothalamus and liver (34), as well as in 3T3-L1 adipocytes (14), prompted us to determine whether TNF- $\alpha$-mediated turnover of STAT5A was related to activation of STAT5 via tyrosine phosphorylation. Hence, we examined the growth hormoneinduced activation of STAT5 tyrosine phosphorylation in the absence or presence of various TNF- $\alpha$ pretreatments. As shown in lane 2 of Fig. 3A, growth hormone induced the tyrosine phosphorylation of STAT5 proteins. However, a 15min treatment with TNF- $\alpha$ (lane 3) did not induce STAT5 activation. Moreover, none of the TNF- $\alpha$ pretreatments $(0.25-2 \mathrm{~h})$ of mature $3 \mathrm{~T} 3-\mathrm{L} 1$ adipocytes resulted in the activation of STAT5 in our studies. In addition, pretreatment with TNF- $\alpha$ did not affect growth hormone-dependent activation of STAT5. We also examined the ability of TNF- $\alpha$ to affect growth hormone-induced STAT5 activation in the presence of cycloheximide. As shown in Fig. 3B, a 6-h TNF- $\alpha$ treatment did not attenuate the ability of acute growth hormone to induce STAT5 phosphorylation. However, a 6-h treatment of both TNF- $\alpha$ and cycloheximide was accompanied by a substantial loss of STAT5A levels and a decrease in growth hormoneinduced STAT5A activation, consistent with the decreased levels of STAT5A total protein. Yet these data demonstrate that the STAT5A can still be activated by growth hormone in the presence of cycloheximide (lane 6), indicating that TNF- $\alpha$ is not inducing STAT5A degradation in a manner associated with STAT5 phosphorylation. The levels of ERK1 are shown to indicate even loading of protein extracts. In summary, the results suggest that cyclohexmide and TNF- $\alpha$ affect STAT5A turnover, independent of transcriptional activation of STAT$5 \mathrm{~A}$, which is modulated by its tyrosine phosphorylation.

To further examine this question, we examined the ability of growth hormone to affect the decay of STAT5 proteins. The results in Fig. 4 demonstrate that growth hormone does not affect STAT5A (Fig. 4A) or STAT5B (Fig. 4B) stability, suggesting that activation of STAT5 proteins is unrelated to the increased turnover observed in the presence of TNF- $\alpha$. Moreover, growth hormone does not rescue the TNF- $\alpha$-induced destabilization of STAT5 proteins (Fig. 4), indicating that TNF- $\alpha$ and growth hormone are independent regulators of STAT5 proteins in cultured adipocytes.

STAT5B is more labile than STAT5A under TNF- $\alpha$-mediated conditions in 3T3-L1 adipocytes. The TNF- $\alpha$-mediated destabilization of STAT5A in the presence of cycloheximide may be specific for STAT5A or also affect the highly homologous STAT5B, which is encoded by a separate gene (24). Previous studies have shown that tyrosine-phosphorylated STAT5 is targeted to the proteasome via the carboxy terminal region of STAT5 that overlaps the transcriptional activation domain (44). STAT5A and STAT5B differ at the carboxy terminal region, and we carried out experiments to examine the stability of STAT5B protein in the presence of TNF- $\alpha$ and cycloheximide. In several independent experiments, we observed that the half-lives of STAT5A $(23.8 \pm 3.8 \mathrm{~h})$ and STAT5B $(24 \pm$ $3.3 \mathrm{~h}$ ) were very similar under basal conditions (cycloheximide treatment alone) in 3T3-L1 adipocytes. However, in the presence of TNF- $\alpha$ and cycloheximide, STAT5B was notably more labile, with a half-life of $0.73 \pm 0.07 \mathrm{~h}$ compared with STAT5A $(1.5 \pm 0.38 \mathrm{~h})$. These studies demonstrate that TNF- $\alpha$ has a substantial effect on the degradation of both STAT5A and STAT5B in adipocytes. In addition, our half-life determinations clearly indicate that STAT5B becomes significantly more unstable than STAT5A in the presence of TNF- $\alpha$
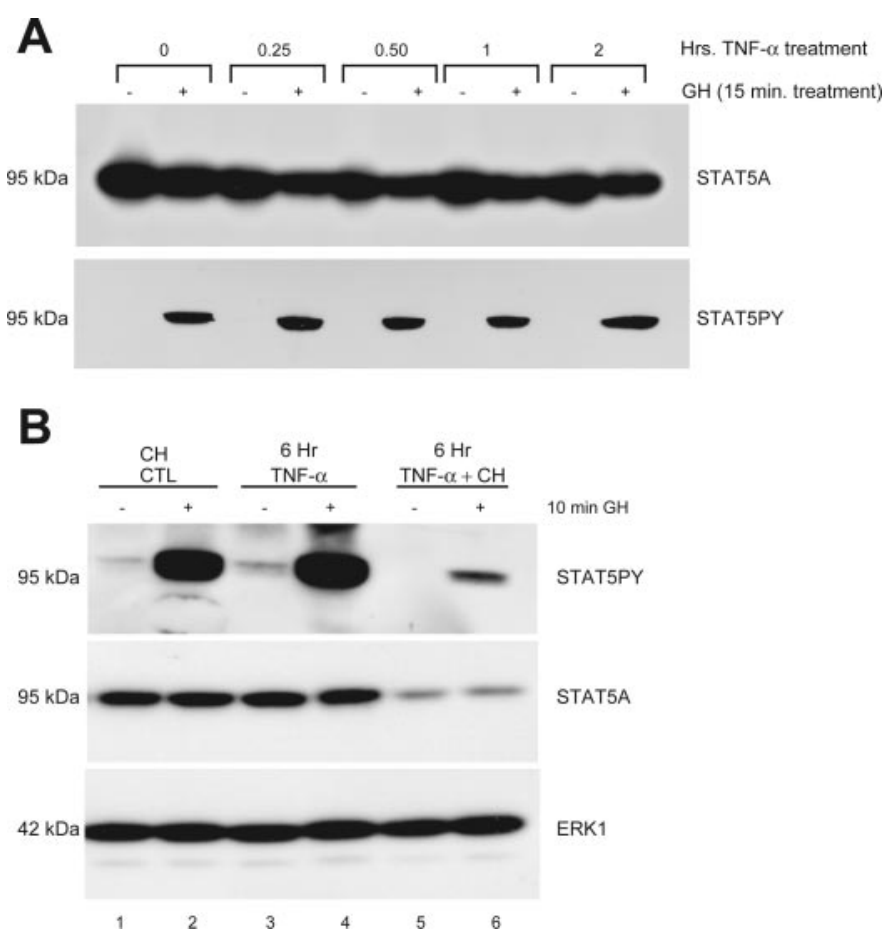

Fig. 3. TNF- $\alpha$ does not activate STAT5A or affect GH-induced STAT5A activation. A: fully differentiated 3T3-L1 adipocytes were pretreated with $5 \mathrm{nM}$ TNF- $\alpha$ for the indicated times before 15 -min incubation with $250 \mathrm{ng} / \mathrm{ml} \mathrm{GH}$. $B$ : mature 3T3-L1 adipocytes were incubated for $6 \mathrm{~h}$ in the presence of $5 \mu \mathrm{M}$ $\mathrm{CH}$ [control (CTL)] alone, $5 \mathrm{nM}$ TNF- $\alpha$ (TNF) alone, or TNF- $\alpha$ and $\mathrm{CH}$ combined (TNF- $\alpha+\mathrm{CH}$ ) before incubation in the absence or presence of $\mathrm{GH}$ $(250 \mathrm{ng} / \mathrm{ml}$ ) for $10 \mathrm{~min}$. For $A$ and $B$, whole cell extracts were harvested, and $100 \mu \mathrm{g}$ of each extract were separated by SDS-PAGE followed by transfer to nitrocellulose. The samples were assayed by Western blot analysis using anti-STAT5A, anti-STAT5-phosphotyrosine (STAT5PY), or anti-ERK1/2 antibodies. This is a representative experiment independently performed 3 times. 
A

$95 \mathrm{kDa}$
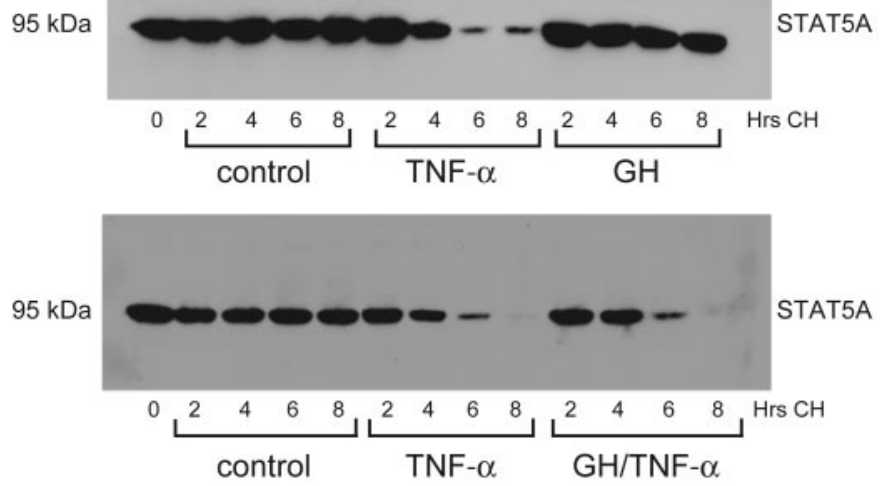

B
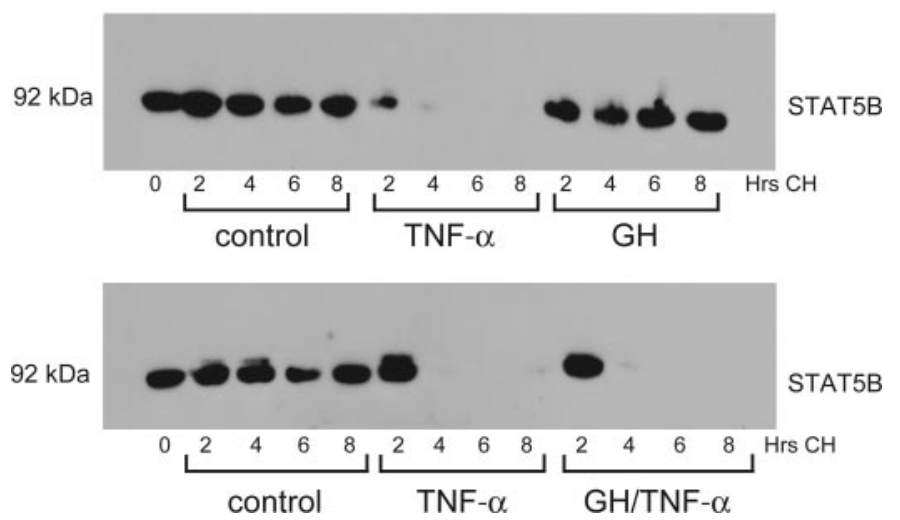

Fig. 4. GH-induced STAT5 phosphorylation does not destabilize STAT5 and does not affect the $\mathrm{CH}$ and TNF- $\alpha$-induced degradation of STAT5. Fully differentiated 3T3-L1 adipocytes were treated with $5 \mu \mathrm{M} \mathrm{CH}$ in the absence (control) or presence of $5 \mathrm{nM} \mathrm{TNF}-\alpha, 250 \mathrm{ng} / \mathrm{ml} \mathrm{GH}$, or both TNF- $\alpha$ and GH $(\mathrm{GH} / \mathrm{TNF}-\alpha)$. Whole cell extracts were harvested at the indicated time points, and $100 \mu \mathrm{g}$ of each extract were separated by SDS-PAGE, followed by transfer to nitrocellulose and analysis by Western blotting using anti-STAT5A antibody $(A)$ or anti-STAT5B antibody $(B)$. Each experiment was carried out in triplicate and performed independently twice.

and cycloheximide. Also, the more rapid degradation of STAT5B is evident in Fig. $4 B$.

$T N F-\alpha$-mediated turnover of STAT5A is affected by NF- $\kappa B$ activity and proteasome activity but is independent of ERK1/2 kinase, p38 MAPK, or phosphatidylinositol 3-kinase. TNF- $\alpha$ mediated signaling involves several pathways, including the p38 and ERK1/2 mitogen-activated kinase pathways $(31,47)$, as well as the NF- $\kappa \mathrm{B}$ pathway (2). We used a range of signaling inhibitors to determine whether these pathways are involved in the TNF- $\alpha$-mediated turnover of STAT5A. As shown in Fig. 5A, a 1-h pretreatment of fully differentiated 3T3-L1 adipocytes with the MEK inhibitor U-0126 (5 $\mu \mathrm{M})$ or the p38 MAPK inhibitor SB-203580 $(10 \mu \mathrm{M})$ did not significantly affect the degradation of STAT5A induced by the presence of TNF- $\alpha$. Indeed, pretreatment with the p38 MAPK inhibitor was associated with a slight increase in the TNF- $\alpha$ mediated turnover of STAT5. These results indicate that TNF$\alpha$-mediated destabilization of STAT5A is independent of these
MAPK signaling pathways. Given the role of the phosphatidylinositol 3-kinase (PI3K)/Akt pathway in insulin signaling in adipocytes (reviewed in Ref. 41) and the effects of TNF- $\alpha$ on insulin sensitivity, we next examined the role of the PI3K/Akt pathway in TNF- $\alpha$-mediated STAT5A turnover. The results in Fig. $5 B$ demonstrate that inhibition of PI3K signaling with a 1 -h pretreatment with wortmannin $(200 \mathrm{nM})$ does not affect TNF- $\alpha$-induced STAT5 turnover. The efficacy of the wortmannin is demonstrated by its ability to inhibit insulin-induced Akt phosphorylation. Similar experiments were conducted to confirm the efficacy of each inhibitor (data not shown). Although inhibition of ERK1 and ERK2, p38 MAPKs, or PI3K did not affect the ability of TNF- $\alpha$ to modulate STAT5 degradation, we did observe a role of the NF-кB pathway. Inhibition of NF- $\kappa B$ activation using the serine protease inhibitor TPCK (10 $\mu \mathrm{M})$ (16) resulted in the stabilization of STAT5A in the presence of TNF- $\alpha$ (Fig. 5C). These observations are consistent with other studies indicating that NF- $\mathrm{kB}$ activation by TNF- $\alpha$ is required for a wide range of TNF- $\alpha$ effects on 3T3-L1 adipocytes (35). Since NF- $\kappa$ B activation occurs via the proteasome-dependent degradation of inhibitory factor ІкB- $\alpha$ (16), we examined the turnover of STAT5A in the presence of the $20 \mathrm{~S}$ proteasome inhibitor MG-132 $(10 \mu \mathrm{M})(21)$. As shown in Fig. $5 D$, inhibition of the $20 \mathrm{~S}$ proteasome stabilized STAT5A compared with TNF- $\alpha$-mediated turnover of STAT5A in the presence of MEK inhibition. However, it is interesting to note that neither TPCK nor MG-132 completely reversed the effects of TNF- $\alpha$, suggesting that additional signaling pathways are involved in this process. For each experiment in Fig. 5, the levels of ERK1 were examined to confirm even loading of protein extracts (data not shown).

\section{DISCUSSION}

It is well established that chronic TNF- $\alpha$ treatment of 3T3-L1 adipocytes results in insulin resistance, and various mechanisms for TNF- $\alpha$-mediated insulin resistance have been described (reviewed in Refs. 18, 36, 46). Microarray studies have demonstrated that TNF- $\alpha$ treatment $(4-24 \mathrm{~h})$ of 3T3-L1 adipocytes mediates the suppression of a range of genes required for insulin sensitivity (35). The decrease in gene expression is accompanied by a decrease in the protein levels of several proteins involved in insulin signaling, confirming an earlier study demonstrating that long-term exposure to TNF- $\alpha$ is associated with a loss of IRS-1 and GLUT4 proteins in 3T3-L1 adipocytes (39). In addition, TNF- $\alpha$ also mediates the loss in the levels of the IR and Akt (6), possibly as a result of downregulation of gene expression in the 3T3-L1 adipocytes (35). In our present study, we observed that TNF- $\alpha$ inhibited the expression of STAT5A, a transcription factor that is important in fat cells $(10,30,38,40)$. However, the TNF- $\alpha$ mediated changes in gene expression did not identify changes in STAT5 mRNA expression, suggesting that the decrease in STAT5 protein that we observed in the presence of TNF- $\alpha$ and cycloheximide is mediated by posttranslational mechanisms.

Our studies demonstrate that TNF- $\alpha$ treatment resulted in a rapid destabilization of both STAT5A and STAT5B proteins in cultured adipocytes. Although STAT5B was more labile than STAT5A, the significance of this observation is not known, as both of these proteins respond similarly to TNF- $\alpha$ and growth hormone treatment. However, there is evidence that these 
A
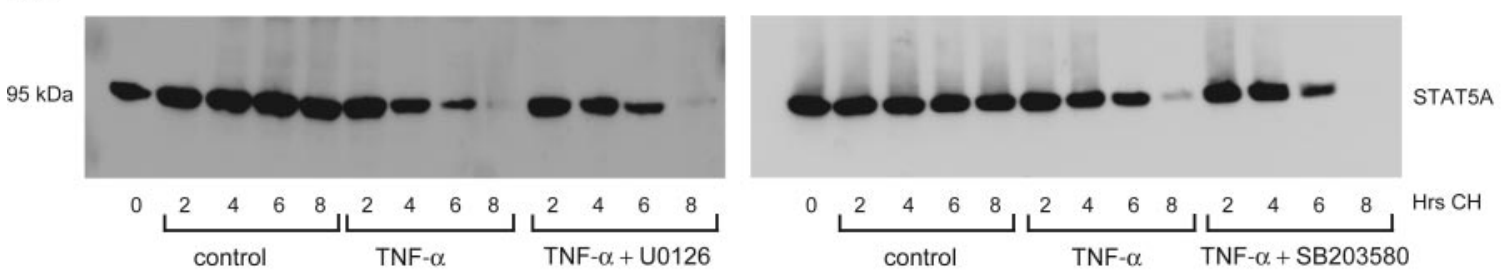

B
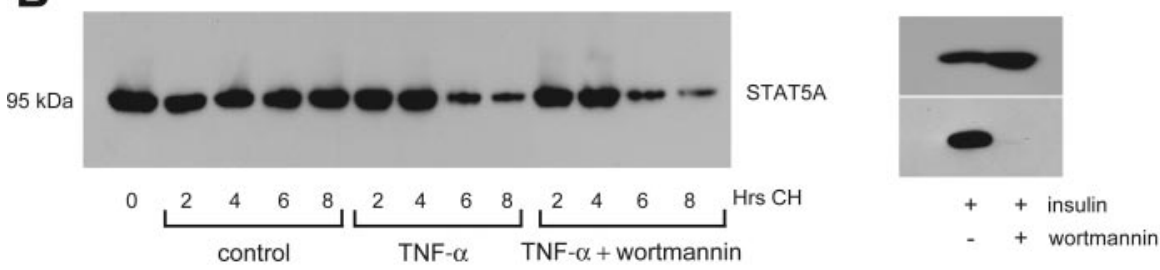

C
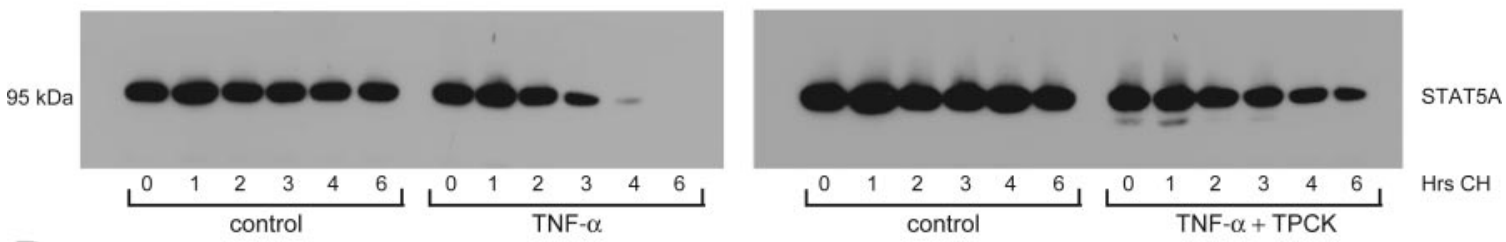

D

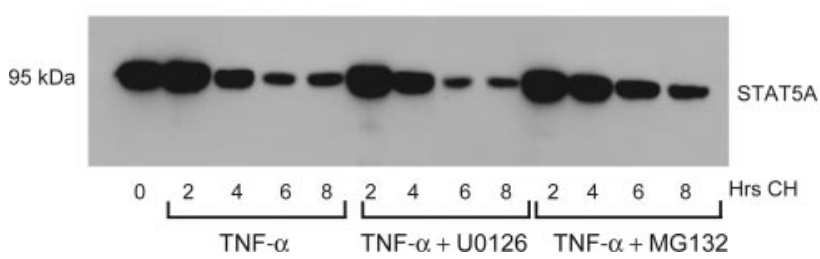

Fig. 5. TNF- $\alpha$ and CH-induced STAT5A degradation is modulated by the proteasome and NF-кB activity, but not ERK1/2, p38 MAPK, or phosphatidylinositol 3-kinase activity. A: fully differentiated 3T3-L1 adipocytes were pretreated with $5 \mu \mathrm{M}$ U-0126 (MEK inhibitor) or $10 \mu \mathrm{M} \mathrm{SB}-203580$ (p38 inhibitor) $1 \mathrm{~h}$ before $5 \mathrm{nM}$ TNF- $\alpha$ and $5 \mu \mathrm{M} \mathrm{CH}$ were added. In addition, adipocytes were pretreated with $200 \mathrm{nM}$ wortmannin (phosphatidylinositol 3-kinase inhibitor); $B$ ), $10 \mu \mathrm{M}$ $N$-p-tosyl-L-phenylalanine chloromethyl ketone (TPCK; NF-кB activation inhibitor; $C$ ), or $10 \mu \mathrm{M}$ MG-132 (20S proteasome inhibitor; $D$ ). Whole cell extracts were harvested, and $100 \mu \mathrm{g}$ of each extract were separated by SDS-PAGE and subjected to Western blot analysis using anti-STAT5A antibody. In each case, STAT5A turnover was examined in the presence of the indicated inhibitor plus TNF- $\alpha$ and was compared with the turnover rate in the absence (control) or presence of TNF- $\alpha$ alone. Each experiment was carried out in triplicate and performed twice independently.

proteins can have nonredundant functions and, hence, may be differentially regulated. The degradation of STAT5 proteins occurred in both the cytosol and nucleus. As shown in Fig. 2, a substantial loss of STAT5A proteins was observed in both the cytosol and nucleus following treatment with TNF- $\alpha$ and cycloheximide. In the cytosolic extracts, reduced levels of STAT5A were also observed following 6- and 8-h treatments. In the nuclear extracts, STAT5A was absent at these time points. We hypothesize that these observations are not mediated by major differences in the kinetic decay profile between nucleus and cytoplasm. We predict that the more rapid loss of STAT5A in the nucleus is due to the fact that there is more STAT5A protein in the nucleus than in the cytosol under the conditions studied in Fig. 2. Hence, it appears to disappear quicker in the location. All of our results suggest that the decay of STAT5A proteins is similar in the cytosol and the nucleus. Moreover, these observations are strongly supported by data in Fig. 4, demonstrating that activation of STAT5A by growth hormone (which results in an increase in nuclear STAT5A) does not affect the decay of STAT5A, nor does it affect the ability or timing of the TNF- $\alpha$-induced degradation of STAT5A.

TNF- $\alpha$-mediated insulin resistance is reported to involve regulation of posttranslational modifications of proteins required for insulin signaling, such as altering the phosphorylation status of the IR and IRS-1 $(8,13,19,20)$. A number of signaling pathways are important in TNF- $\alpha$-mediated responses in adipocytes that lead to insulin resistance. Among these are the p42/44 (ERK1/2) MAPK (5), p38 MAPK (37), and NF-кB $(35,36)$ pathways. ERK1/2 activity plays a role in TNF- $\alpha$-mediated serine/threonine phosphorylation of IRS-1, and inhibition of ERK1/2 activity restores insulin sensitivity in the presence of TNF- $\alpha(5,11)$. A role for p38 MAPK activation in TNF- $\alpha$-induced insulin resistance has been demonstrated in brown adipocytes (17), as well as human adipocytes (3), although the contribution is considered to be less pro- 
nounced than the effect mediated by the ERK1/2 pathway (11, 37). Indeed, additional studies in brown adipocytes have indicated that inhibition of p38 MAPK, in contrast to ERK1/2, potentiates the negative effect of TNF- $\alpha$ on insulin signaling (43). The NF-кB pathway also plays a central role in TNF- $\alpha-$ induced insulin resistance in adipocytes, mediating the regulation of a range of factors, including IR, IRS-1, and the Akt protein kinase B $(35,36)$. Interestingly, a number of studies show that TNF- $\alpha$ stimulates Akt phosphorylation in an NF$\kappa \mathrm{B}$-dependent manner $(26,27)$. In addition, TNF- $\alpha$-induced NF- $\kappa \mathrm{B}$ activity is independent of ERK1/2 and p38 MAPK activity in brown adipocytes (42), suggesting that TNF- $\alpha$ may exert effects on insulin sensitivity independently of ERK1/2 and $\mathrm{p} 38$ MAPK activity. In support of this notion, TNF- $\alpha$ regulation of resistin, an adipokine associated with insulin resistance, is independent of ERK1/2 and p38 activation in 3T3-L1 adipocytes (6).

Our results indicate that TNF- $\alpha$ also mediates the turnover of STAT5 proteins in adipocytes in a manner that is influenced by NF-кB activity, but clearly independent of ERK $1 / 2$ and p38 MAPK activation or phosphorylation of Akt. However, it is interesting to note that inhibition of p38 activity has a modest effect on TNF- $\alpha$-mediated STAT5 turnover, and inhibition of ERK1/2 had no effect on this process. These data are in agreement with previous studies showing that the ERK1/2 and p38 signaling pathways do not play equivalent roles in TNF$\alpha$-mediated insulin resistance $(23,24)$. To our knowledge, this is the first report of TNF- $\alpha$-mediated destabilization of STAT5 proteins in adipocytes. Our results indicate that TNF- $\alpha$ induces a significantly accelerated decay rate for STAT5 in 3T3-L1 adipocytes that is influenced by activity of the NF-кB pathway. Although NF- $\mathrm{KB}$ activation is well known to depend on proteasome activity via degradation of inhibitory factor I $\mathrm{K} B-\alpha$ (16), STAT5 is also a known substrate of the 26S proteasome (44). The observed changes in the decay rates for STAT5A and STAT5B are pronounced, and the usually abundant and stable STAT5 proteins (23- to 24-h half-lives) are converted to highly unstable proteins with half-lives reduced to 90 and $44 \mathrm{~min}$, respectively. These changes in stability of the STAT5 proteins suggest that TNF- $\alpha$-mediated activation of NF- $\kappa \mathrm{B}$ may alter $26 \mathrm{~S}$ proteasome recognition of the STAT5 proteins in adipocytes in a manner that is independent of STAT5 tyrosine phosphorylation.

The present results suggest that a protein that is modified by TNF- $\alpha$ signaling mediates the degradation of STAT5 proteins in adipocytes. However, TNF- $\alpha / \mathrm{NF}-\kappa \mathrm{B}-$ mediated destabilization of STAT5 in 3T3-L1 adipocytes appears to be unrelated to growth hormone-induced activation of STAT5 proteins via tyrosine phosphorylation. Moreover, growth hormone activation of STAT5 does not alter STAT5 protein stability. Although TNF- $\alpha$ and growth hormone activate phosphorylation of JAK2 (7), the minimal levels of TNF- $\alpha$-induced STAT5 phosphorylation in our experiments suggests that JAK2 receptors are not involved in the TNF- $\alpha$-dependent destabilization of STAT5. In addition, the low level of STAT5 tyrosine phosphorylation associated with TNF- $\alpha$ treatment also suggests that dephosphorylation mediated by the PTP-1B cytoplasmic phosphatase is unlikely to be involved in this process. Nonetheless, there are intriguing possibilities for factors that may be involved in the accelerated degradation of STAT5. One of these is the suppressor of cytokine signaling (SOCS) family of adapter proteins that act as negative regulators of cytokine signaling by targeting substrates to the ubiquitin-proteasome system (reviewed in Ref. 48). Both TNF- $\alpha$ and growth hormone stimulate an increase in SOCS-1 and SOCS-3, resulting in the downregulation of JAK/STAT pathways through interactions with the phosphorylated JAK2 receptor (7). However, our studies argue against a role for SOCS adaptors in the destabilization of STAT5 due to the differential effects of growth hormone and TNF- $\alpha$ and recent studies by our laboratory demonstrating that expression of SOCS-3 does not induce IRS-1 degradation in adipocytes (15). Another interesting possibility is c-Cbl, a cytoplasmic protein that functions as a ubiquitin ligase to target substrates for degradation and has been shown to maybe play a role in regulating insulin sensitivity in adipocytes $(23,29)$. Recent studies in NIH 3 T3 cells show that c-Cbl downregulates growth hormone-stimulated STAT5 activity by targeting STAT5 to the proteasome (12). These studies are similar to our results in that c-Cbl targets STAT5 for degradation independently of JAK2 or STAT5 phosphorylation and does not depend on translocation of STAT5 to the nucleus. Although our present studies do not address this issue, other studies have demonstrated that $\mathrm{c}-\mathrm{Cbl}$ participates in signaling mediated by the TNF- $\alpha$ family of proteins (1).

It is important to note that our findings occur in the context of TNF- $\alpha$ signaling in the presence of cycloheximide. Although the presence of $5 \mu \mathrm{M}$ cycloheximide in this study did not result in substantial morphological changes indicative of apoptosis, the combination of TNF- $\alpha$ and cycloheximide has been associated with potentiation of TNF- $\alpha$ effects in a range of cell types $(9,28,32,49)$. Indeed, our studies in 3T3-L1 adipocytes are consistent with an earlier study indicating that human fat cells are rendered significantly more sensitive to the effects of TNF- $\alpha$ in the presence of cycloheximide (9). Interestingly, inhibition of TNF- $\alpha$-induced apoptosis in human fat cells depends on the IGF-I (9), and growth hormone stimulation of IGF-I expression is mediated by STAT5 $(4,45)$.

Taken together, these studies demonstrate that potentiation of TNF- $\alpha$ signaling significantly influences the stability of STAT5 proteins in adipocytes in a manner that correlates with NF- $\kappa \mathrm{B}$ activation. These data represent an additional pathway that TNF- $\alpha$ uses to alter expression levels of important adipocyte proteins such as STAT5A. In addition, destabilization of the unphosphorylated STAT5 proteins via the TNF- $\alpha$ pathway indicates that the STAT5 proteins are regulated in the cytoplasm of fat cells in a manner that is independent of their activation and function as transcription factors. STAT proteins are found in cytoplasmic multisubunit complexes that may serve as platforms for STAT protein interactions (reviewed in Ref. 22), and regulating the levels of STAT5 in these complexes may play a role in insulin signaling in adipocytes. In summary, our studies reveal that STAT5 proteins can be significantly regulated by altering their half-lives in a manner that is independent of their presence in the nucleus.

\section{GRANTS}

This work was supported by an American Heart Association Postdoctoral Fellowship to Z. E. Floyd and National Institute of Diabetes and Digestive and Kidney Diseases Grant R01-DK-52968-05 to J. M. Stephens.

Present addresses: Z. E. Floyd: Pennington Biomedical Research Center, Baton Rouge, LA 70808; B. M. Segura: Wake Forest University School of Medicine, Winston-Salem, NC 27157. 


\section{REFERENCES}

1. Arron JR, Vologodskaia M, Wong BR, Naramura M, Kim N, Gu H, Choi Y. A positive regulatory role for $\mathrm{Cbl}$ family proteins in tumor necrosis factor-related activation-induced cytokine (trance) and CD40Lmediated Akt activation. J Biol Chem 276: 30011-30017, 2001.

2. Bouwmeester T, Bauch A, Ruffner H, Angrand PO, Bergamini G, Croughton K, Cruciat C, Eberhard D, Gagneur J, Ghidelli S, Hopf C, Huhse B, Mangano R, Michon AM, Schirle M, Schlegl J, Schwab M, Stein MA, Bauer A, Casari G, Drewes G, Gavin AC, Jackson DB, Joberty G, Neubauer G, Rick J, Kuster B, and Superti-Furga G. A physical and functional map of the human TNF-alpha/NF-kappa B signal transduction pathway. Nat Cell Biol 6: 97-105, 2004.

3. Carlson CJ, Koterski S, Sciotti RJ, Poccard GB, Rondinone CM. Enhanced basal activation of mitogen-activated protein kinases in adipocytes from type 2 diabetes: potential role of $\mathrm{p} 38$ in the downregulation of GLUT4 expression. Diabetes 52: 634-641, 2003.

4. Chia DJ, Ono M, Woelfle J, Schlesinger-Massart M, Jiang H, Rotwein P. Characterization of distinct Stat5b binding sites that mediate growth hormone-stimulated IGF-I gene transcription. J Biol Chem 281: 31903197, 2006.

5. Engelman JA, Berg AH, Lewis RY, Lisanti MP, Scherer PE. Tumor necrosis factor alpha-mediated insulin resistance, but not dedifferentiation, is abrogated by MEK1/2 inhibitors in 3T3-L1 adipocytes. Mol Endocrinol 14: $1557-1569,2000$.

6. Fasshauer M, Klein J, Neumann S, Eszlinger M, Paschke R. Tumor necrosis factor alpha is a negative regulator of resistin gene expression and secretion in 3T3-L1 adipocytes. Biochem Biophys Res Commun 288: 1027-1031, 2001.

7. Fasshauer M, Kralisch S, Klier M, Lossner U, Bluher M, Klein J, Paschke R. Insulin resistance-inducing cytokines differentially regulate SOCS mRNA expression via growth factor- and Jak/Stat-signaling pathways in 3T3-L1 adipocytes. J Endocrinol 181: 129-138, 2004.

8. Feinstein R, Kanety H, Papa MZ, Lunenfeld B, Karasik A. Tumor necrosis factor-alpha suppresses insulin-induced tyrosine phosphorylation of insulin receptor and its substrates. J Biol Chem 268: 26055-26058, 1993.

9. Fischer-Posovszky P, Tornqvist H, Debatin KM, Wabitsch M. Inhibition of death-receptor mediated apoptosis in human adipocytes by the insulin-like growth factor I (IGF-I)/IGF-I receptor autocrine circuit. Endocrinology 145: 1849-1859, 2004.

10. Floyd ZE, Stephens JM. STAT5A promotes adipogenesis in nonprecursor cells and associates with the glucocorticoid receptor during adipocyte differentiation. Diabetes 52: 308-314, 2003.

11. Fujishiro M, Gotoh Y, Katagiri H, Sakoda H, Ogihara T, Anai M, Onishi Y, Ono H, Abe M, Shojima N, Fukushima Y, Kikuchi M, Oka Y, Asano T. Three mitogen-activated protein kinases inhibit insulin signaling by different mechanisms in 3T3-L1 adipocytes. Mol Endocrinol 17: 487-497, 2003.

12. Goh EL, Zhu T, Leong WY, Lobie PE. c-Cbl is a negative regulator of GH-stimulated STAT5-mediated transcription. Endocrinology 143: 3590$3603,2002$.

13. Guo D, Donner DB. Tumor necrosis factor promotes phosphorylation and binding of insulin receptor substrate 1 to phosphatidylinositol 3-kinase in 3T3-L1 adipocytes. J Biol Chem 271: 615-618, 1996.

14. Guo D, Dunbar JD, Yang CH, Pfeffer LM, Donner DB. Induction of Jak/STAT signaling by activation of the type 1 TNF receptor. $J$ Immunol 160: 2742-2750, 1998.

15. He F, Stephens JM. Induction of SOCS-3 is insufficient to confer IRS-1 protein degradation in 3T3-L1 adipocytes. Biochem Biophys Res Commun 344: 95-98, 2006.

16. Henkel T, Machleidt T, Alkalay I, Kronke M, Ben-Neriah Y, Baeuerle PA. Rapid proteolysis of I kappa B-alpha is necessary for activation of transcription factor NF-kappa B. Nature 365: 182-185, 1993.

17. Hernandez R, Teruel T, De Alvaro C, Lorenzo M. Rosiglitazone ameliorates insulin resistance in brown adipocytes of Wistar rats by impairing TNF-alpha induction of p38 and p42/p44 mitogen-activated protein kinases. Diabetologia 47: 1615-1624, 2004.

18. Hotamisligil GS. Molecular mechanisms of insulin resistance and the role of the adipocyte. Int J Obes Relat Metab Disord 24, Suppl 4: S23-S27, 2000.

19. Hotamisligil GS, Peraldi P, Budavari A, Ellis R, White MF, Spiegelman BM. IRS-1-mediated inhibition of insulin receptor tyrosine kinase activity in TNF-alpha- and obesity-induced insulin resistance. Science 271: 665-668, 1996.

20. Kanety H, Feinstein R, Papa MZ, Hemi R, Karasik A. Tumor necrosis factor alpha-induced phosphorylation of insulin receptor substrate-1 (IRS1). Possible mechanism for suppression of insulin-stimulated tyrosine phosphorylation of IRS-1. J Biol Chem 270: 23780-23784, 1995.

21. Lee DH, Goldberg AL. Proteasome inhibitors: valuable new tools for cell biologists. Trends Cell Biol 8: 397-403, 1998.

22. Levy DE, Darnell JE Jr. Stats: transcriptional control and biological impact. Nat Rev Mol Cell Biol 3: 651-662, 2002.

23. Liu J, DeYoung SM, Hwang JB, O'Leary EE, Saltiel AR. The roles of Cbl-b and c-Cbl in insulin-stimulated glucose transport. J Biol Chem 278: 36754-36762, 2003.

24. Liu X, Robinson GW, Gouilleux F, Groner B, Hennighausen L. Cloning and expression of Stat5 and an additional homologue (Stat5b) involved in prolactin signal transduction in mouse mammary tissue. Proc Natl Acad Sci USA 92: 8831-8835, 1995.

25. Medina EA, Afsari RR, Ravid T, Castillo SS, Erickson KL, Goldkorn T. Tumor necrosis factor- $\alpha$ decreases Akt protein levels in 3T3-L1 adipocytes via the caspase-dependent ubiquitination of Akt. Endocrinology 146: 2726-2735, 2005.

26. Meng F, D'Mello SR. NF-kappaB stimulates Akt phosphorylation and gene expression by distinct signaling mechanisms. Biochim Biophys Acta 1630: 35-40, 2003.

27. Meng F, Liu L, Chin PC, D'Mello SR. Akt is a downstream target of NF-kappa B. J Biol Chem 277: 29674-29680, 2002.

28. Miura M, Friedlander RM, Yuan J. Tumor necrosis factor-induced apoptosis is mediated by a CrmA-sensitive cell death pathway. Proc Natl Acad Sci USA 92: 8318-8322, 1995.

29. Molero JC, Jensen TE, Withers PC, Couzens M, Herzog H, Thien CB, Langdon WY, Walder K, Murphy MA, Bowtell DD, James DE, Cooney GJ. c-Cbl-deficient mice have reduced adiposity, higher energy expenditure, and improved peripheral insulin action. J Clin Invest 114: 1326-1333, 2004.

30. Nanbu-Wakao R, Morikawa Y, Matsumura I, Masuho Y, Muramatsu MA, Senba E, Wakao H. Stimulation of 3T3-L1 adipogenesis by signal transducer and activator of transcription 5. Mol Endocrinol 16: 15651576, 2002.

31. Raingeaud J, Gupta S, Rogers JS, Dickens M, Han J, Ulevitch RJ, Davis RJ. Pro-inflammatory cytokines and environmental stress cause p38 mitogen-activated protein kinase activation by dual phosphorylation on tyrosine and threonine. J Biol Chem 270: 7420-7426, 1995.

32. Reid TR, Torti FM, Ringold GM. Evidence for two mechanisms by which tumor necrosis factor kills cells. J Biol Chem 264: 4583-4589, 1989.

33. Richter HE, Albrektsen T, Billestrup N. The role of signal transducer and activator of transcription 5 in the inhibitory effects of GH on adipocyte differentiation. J Mol Endocrinol 30: 139-150, 2003.

34. Rizk NM, Stammsen D, Preibisch G, Eckel J. Leptin and tumor necrosis factor-alpha induce the tyrosine phosphorylation of signal transducer and activator of transcription proteins in the hypothalamus of normal rats in vivo. Endocrinology 142: 3027-3032, 2001.

35. Ruan H, Hacohen N, Golub TR, Van Parijs L, Lodish HF. Tumor necrosis factor-alpha suppresses adipocyte-specific genes and activates expression of preadipocyte genes in 3T3-L1 adipocytes: nuclear factorkappaB activation by TNF-alpha is obligatory. Diabetes 51: 1319-1336, 2002.

36. Ruan H, Lodish HF. Insulin resistance in adipose tissue: direct and indirect effects of tumor necrosis factor-alpha. Cytokine Growth Factor Rev 14: 447-455, 2003.

37. Ryden M, Dicker A, van Harmelen V, Hauner H, Brunnberg M, Perbeck L, Lonnqvist F, Arner P. Mapping of early signaling events in tumor necrosis factor-alpha-mediated lipolysis in human fat cells. $J$ Biol Chem 277: 1085-1091, 2002.

38. Shang CA, Waters MJ. Constitutively active signal transducer and activator of transcription 5 can replace the requirement for growth hormone in adipogenesis of 3T3-F442A preadipocytes. Mol Endocrinol 17: 2494-2508, 2003.

39. Stephens JM, Lee J, Pilch PF. Tumor necrosis factor-alpha-induced insulin resistance in 3T3-L1 adipocytes is accompanied by a loss of insulin receptor substrate-1 and GLUT4 expression without a loss of insulin receptor-mediated signal transduction. J Biol Chem 272: 971-976, 1997. 
40. Stewart WC, Baugh JE Jr, Floyd ZE, and Stephens JM. STAT 5 activators can replace the requirement of FBS in the adipogenesis of 3T3-L1 cells. Biochem Biophys Res Commun 324: 355-359, 2004.

41. Summers SA, Whiteman EL, Birnbaum MJ. Insulin signaling in the adipocyte. Int J Obes Relat Metab Disord 24, Suppl 4: S67-S70, 2000.

42. Valladares A, Alvarez AM, Ventura JJ, Roncero C, Benito M, Porras A. p38 mitogen-activated protein kinase mediates tumor necrosis factor-alpha-induced apoptosis in rat fetal brown adipocytes. Endocrinology 141: 4383-4395, 2000.

43. Valladares A, Roncero C, Benito M, Porras A. TNF-alpha inhibits UCP-1 expression in brown adipocytes via ERKs. Opposite effect of p38 MAPK. FEBS Lett 493: 6-11, 2001.

44. Wang D, Moriggl R, Stravopodis D, Carpino N, Marine JC, Teglund S, Feng J, Ihle JN. A small amphipathic alpha-helical region is required for transcriptional activities and proteasome-dependent turnover of the tyrosine-phosphorylated Stat5. EMBO J 19: 392-399, 2000
45. Wang Y, Jiang $\mathbf{H}$. Identification of a distal STAT5-binding DNA region that may mediate growth hormone regulation of insulin-like growth factor-I gene expression. J Biol Chem 280: 10955-10963, 2005.

46. Warne JP. Tumour necrosis factor alpha: a key regulator of adipose tissue mass. J Endocrinol 177: 351-355, 2003.

47. Winston BW, Remigio LK, Riches DW. Preferential involvement of MEK1 in the tumor necrosis factor-alpha-induced activation of $\mathrm{p} 42 \mathrm{mapk} /$ erk2 in mouse macrophages. J Biol Chem 270: 27391-27394, 1995.

48. Wormald S, Hilton DJ. Inhibitors of cytokine signal transduction. J Biol Chem 279: 821-824, 2004.

49. Xu J, Yeh CH, Chen S, He L, Sensi SL, Canzoniero LM, Choi DW, Hsu CY. Involvement of de novo ceramide biosynthesis in tumor necrosis factor-alpha/cycloheximide-induced cerebral endothelial cell death. J Biol Chem 273: 16521-16526, 1998.

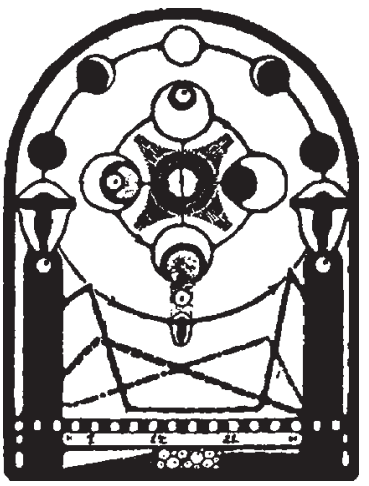

